\title{
Flow mechanism of the Des Moines lobe of the Laurentide ice sheet
}

\author{
Thomas S. HOOYER, ${ }^{1}$ Neal R. IVERSON ${ }^{2}$ \\ ${ }^{1}$ Wisconsin Geological and Natural History Survey, 3817 Mineral Point Road, Madison, Wisconsin 53705, U.S.A. \\ E-mail: tshooyer@facstaff.wisc.edu \\ ${ }^{2}$ Department of Geological and Atmospheric Science, Iowa State University, Ames, Iowa 50011, U.S.A.
}

\begin{abstract}
Rapid flow of the Des Moines lobe of the Laurentide ice sheet may have been related to its unlithified substrate. New reconstructions of the lobe, based on moraine elevations, sediment subsidence during moraine deposition, and flow-direction indicators, indicate that the lobe may have been $\sim 3$ times thicker than in previous reconstructions. Nevertheless, implied basal shear stresses are $<15 \mathrm{kPa}$, so internal ice deformation was not significant. Instead, the lobe likely moved by a combination of sliding, plowing of particles through the bed surface, and bed shear. Consolidation tests on basal till yield preconsolidation stresses of $125-300 \mathrm{kPa}$, so effective normal stresses on the bed were small. A model of sliding and plowing indicates that at such stresses most particles gripped by the ice may have plowed easily through the till bed, resulting in too small a shear traction on the bed to shear it at depth. Consistent with this prediction, measurements of orientations of clasts in basal till yield a weak fabric, implying pervasive bed shear strain less than $\sim 2$, although some stronger fabrics have been reported by others. We infer, tentatively, that movement was principally at the bed surface by plowing.
\end{abstract}

\section{INTRODUCTION}

Fluctuations of the Laurentide ice sheet may have driven climate change over various time-scales during the Pleistocene by influencing continental water balances, atmospheric and oceanic circulation, vegetation, and land-surface albedo (e.g. Clark and others, 1999). Fluctuations of the ice sheet depended on its flow mechanisms, particularly on rapid basal motion that may have been facilitated by a thawed, unlithified substrate (e.g. MacAyeal, 1993; Clark, 1994; Marshall and Clarke, 1997).

Glaciers may move over such a substrate by two processes: decoupling of ice from the sediment bed and by shearing of the bed at depth. Decoupling involves both sliding of ice past clasts that protrude from the bed into the glacier sole and plowing of such clasts through the bed surface (e.g. Brown and others, 1987). Bed shear may occur either as pervasive deformation in a zone that is decimeters to meters thick immediately beneath the glacier sole (e.g. Alley and others, 1986) or as deformation localized at one or several discrete depths below the glacier sole (e.g. Truffer and others, 2000).

Determining the relative importance of these processes would focus efforts to formulate a general constitutive relation for basal motion. The dominant basal flow mechanism also bears on glacial landform development and sediment transport. For example, pervasive deformation of till substrates may have influenced the formation of drumlins (e.g. Smalley and Unwin, 1968; Boulton, 1987), eskers (Clark and Walder, 1994) and boulder pavements (Clark, 1991). Such deformation also may have been responsible for high sediment fluxes from some Pleistocene ice masses (Alley, 1991; Jenson and others, 1995; Hooke and Elverhøi, 1996; Dowdeswell and Siegert, 1999). A first step toward testing these hypotheses is assessing the importance of bed deformation in glacier flow.

Measurements at the bottoms of modern glaciers with unlithified beds have yielded conflicting interpretations of basal flow mechanisms. Borehole records of bed deformation at Storglaciären, Sweden (Iverson, and others, 1995; Hooke and others, 1997), and of sliding at Trapridge Glacier, Canada (Blake and others, 1994; Fischer and Clarke, 1997), indicate that when basal water pressure is sufficiently high, motion is focused either at the glacier sole or within the bed only centimeters beneath the glacier sole. Similarly, at the base of a borehole at Whillans Ice Stream, West Antarctica, where basal water pressure is continuously high, motion was focused within centimeters of the ice/bed interface (Engelhardt and Kamb, 1998). However, these data are contradicted by other measurements. Beneath Breiðamerkurjökull, Iceland, most basal motion is distributed across a $0.5-1.0 \mathrm{~m}$ thick shear zone in till below the glacier sole (Boulton and Hindmarsh, 1987; Boulton and Dobbie, 1993). Borehole measurements at Bakaninbreen, Svalbard (Porter and others, 1997; Porter and Murray, 2001), Columbia Glacier, Alaska (Humphrey and others, 1993), and Ice Stream D, West Antarctica (Kamb, 2001), also indicate that significant deformation extends to depth in the bed. Particularly intriguing borehole measurements with tiltmeters at Black Rapids Glacier, Alaska, indicate that, despite the thawed bed there, the bed deforms only at depths greater than $2 \mathrm{~m}$, accounting for most basal motion (Truffer and others, 2000).

In this paper, we evaluate possible flow mechanisms of the Des Moines lobe, a part of the Laurentide ice sheet that rested on unlithified sediment and that sometimes apparently flowed rapidly (Clayton and Moran, 1982). We first extend earlier work (Clark, 1992) to reconstruct the surface 


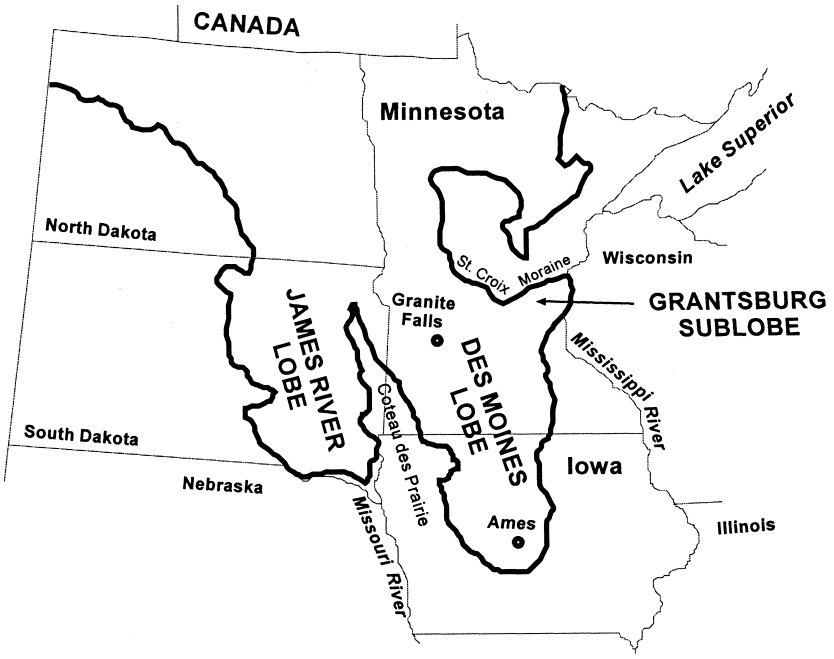

Fig. 1. Maximum extent of the DML and the Grantsburg sublobe $\sim 13800$ radiocarbon years before present.

morphology of the lobe and estimate basal shear stresses. The possible range of effective normal stress on the bed during the glacier's maximum is then estimated from consolidation tests on the basal till of the lobe. Over the indicated range of effective normal stress, the shear traction supported by the ice/bed interface is estimated using a model of sliding and plowing (Iverson, 1999) and compared with the shear strength of the till bed to assess whether shear at depth in the bed was likely. The model results are then compared with field measurements of clast fabric from basal till, which bear on whether the bed sheared pervasively to high strains (e.g. Alley and others, 1986).

\section{REGIONAL SETTING}

The Des Moines lobe (DML) was the largest of several lobes of the Laurentide ice sheet that extended into the mid-continent region of North America during the last glaciation. At its maximum extent, approximately 13800 radiocarbon years ago, the lobe was up to $250 \mathrm{~km}$ wide and covered $>10^{5} \mathrm{~km}^{2}$ in southern Minnesota and north central Iowa (Fig. 1). An arm of the DML, the Grantsburg sub-lobe, flowed to the northeast into western Wisconsin. In Minnesota, the lobe was bounded by glacial deposits of the Coteau des Prairies to the southwest and by the Saint Croix moraine of the Superior lobe to the northeast.

Reconstructions of the surface morphology of the DML at its maximum extent have indicated that it was probably thin and gently sloping (Mathews, 1974; Clark, 1992; Brevik, 2000). Driving stresses (downslope component of the glacier's weight per unit bed area) calculated from the reconstruction of Clark (1992) range from 0.7 to $4.3 \mathrm{kPa}$, more than 10 times smaller than that considered typical for glaciers (Paterson, 1994, p. 240). Furthermore, rates of ice-margin advance were on the order of $1700 \mathrm{~m} \mathrm{a}^{-1}$, if the best radiocarbon chronology, corrected for variable atmospheric production of $\mathrm{C}^{14}$ (Stuiver and others, 1998), is taken at face value (Clayton and Moran, 1982; Clayton and others, 1985). Based largely on its inferred high speed and low driving stresses, the DML has been compared to the ice streams of the Siple Coast in West Antarctica (e.g. Clark, 1992).

The till of the DML, called the New Ulm till in Minnesota and defined as part of the Dows Formation in Iowa, is 5-20 m thick. In Iowa the till is divided into the Alden Member and

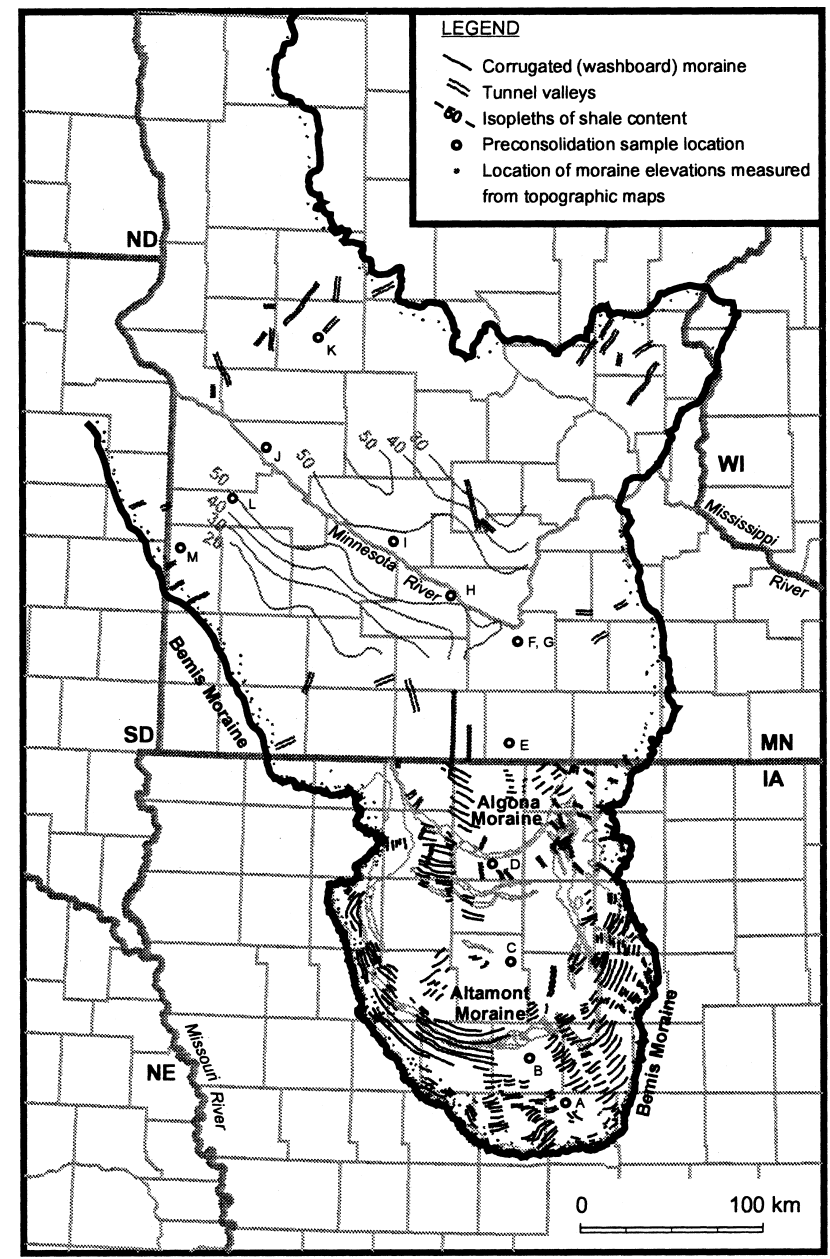

Fig. 2. Geomorphic features and shale isopleths of the DML. Letters indicate locations of samples collected for consolidation tests. Small dots near the glacier margin are locations on the Bemis Moraine where elevations were measured from topographic maps.

the overlying Morgan Member (Hallberg and Kemmis, 1986). The Alden Member is interpreted to be a basal till and consists primarily of a dense, homogeneous diamicton. The diamicton of the Morgan Member, not present everywhere, is texturally heterogeneous and is interpreted to be a supraglacial till deposited in ice-marginal settings (Luttenegger and others, 1983). The DML till generally overlies unlithified sediment $>20 \mathrm{~m}$ thick. The maximum extent of the DML is well defined by the Bemis Moraine, a 5-15 $\mathrm{km}$ wide band of elevated hummocky topography (Fig. 2). The moraine is approximately the same age as the Pine City moraine of the Grantsburg sub-lobe (Wright and others, 1973), which is, hereinafter, considered part of the Bemis Moraine. Other moraines within the margin of the Bemis Moraine represent subsequent marginal positions of the lobe, including the Altamont and Algona moraines (Fig. 2). Other prominent geomorphic features of the lobe include corrugated (washboard) moraine (Gwynne, 1942, 1951; Stewart and others, 1988; Colgan, 1996) and tunnel valleys (Patterson, 1996).

Fossil insects (Schwert and Torpen, 1996), herbaceous plants (Baker, 1996) and trees (Bettis and others, 1996) found near the base of the Dows Formation, and the lack of evidence of permafrost features in the area, indicate that the lobe advanced into a relatively warm (non-arctic) climate. Moreover, tunnel valleys indicate that there was significant meltwater at the bed. These observations, although not conclusive, indicate that the bed was likely thawed. 

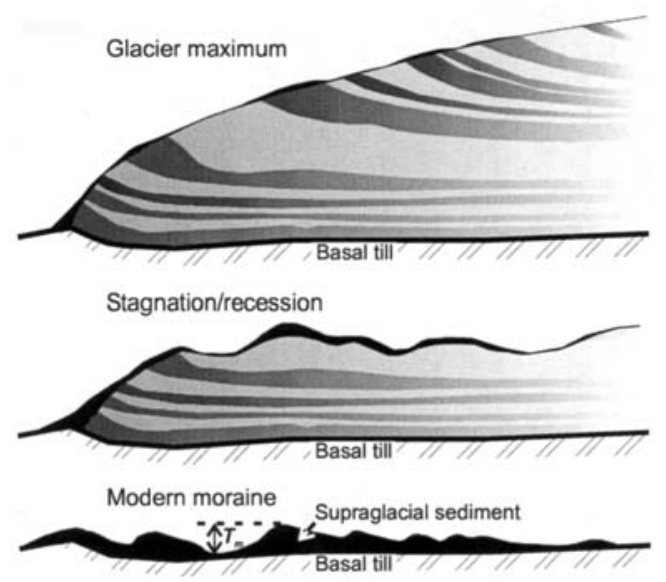

Fig. 3. One possible style of moraine formation at the margin of the DML. Elevation of the modern moraine may be significantly less than that of the former ice surface at that location. Maximum relief of the modern moraine provides a minimum value of the thickness of supraglacial sediment, $T_{\mathrm{m}}$.

\section{RECONSTRUGTION AND BASAL SHEAR STRESS}

To reconstruct the DML, we follow the method outlined by Clark (1992), who used the elevation of the Bemis Moraine and flowlines inferred from corrugated moraines and shale isopleths to estimate the geometry of the lobe. We consider additional flowline indicators and also examine the sensitivity of the reconstruction to the elevation of the Bemis Moraine, which may have been ice-cored during deposition and hence higher than at present. Terminal-moraine elevations and flow-direction indicators have been used to reconstruct other lobes of the Laurentide ice sheet (Clark, 1992; Colgan, 1996, 1999; Colgan and Mickelson, 1997; Socha and others, 1999) with this method. Contrary to some assertions in the literature, applying this method to reconstruct ice lobes does not involve assumptions regarding either steadystate glacier flow or ice rheology.

Following Clark (1992), we assume points of highest elevation on the Bemis Moraine reflect the elevation of the margin of the lobe at its maximum extent. The elevation of the highest point on the moraine is determined every 2$5 \mathrm{~km}$ from 1:24000 topographic maps. Then various flow indicators are used to draw contours of the glacier surface that are perpendicular to the flow direction and that connect points of equal moraine elevation on either side of the lobe. The ice-flow direction is determined in part from corrugated ground moraine, ubiquitous in Iowa (Fig. 2) and assumed to lie perpendicular to flow. The concentration of sand-sized shale fragments in the basal till is also used as a flow-direction indicator in Minnesota (Fig. 2). A reduction in concentration of these particles is interpreted to have resulted from comminution that increased with transport distance from the shale source outcrop (Matsch, 1972). Isopleths of shale content, therefore, are assumed to have been perpendicular to flow (Clark, 1992). Tunnel valleys (Patterson, 1996) are assumed to lie parallel to flow and provide an additional constraint not available to Clark (1992).

This method of reconstruction is uncertain for several reasons. One concern is that the origin of corrugated moraines is not well known. However, their tendency to lie perpendicular to tunnel valleys (Fig. 2) indicates that they lie perpendicular to ice flow. The orientations of pebbles, bul- let stones and slickensides within the moraines (Stewart and others, 1988) also support this assumption. Another concern is that not all flow indicators may have formed during the lobe's maximum extent. If so, their internally consistent orientations indicate that flow directions during retreat or minor advances of the lobe must not have deviated greatly from those when the glacier was at its maximum extent.

Another source of error is that high points along the terminal moraine of the lobe may be at a lower elevation than the former ice surface at those points. End-moraine deposition commonly involves the formation of an ice-cored moraine (Fig. 3) (e.g. Hooke, 1970; Østrem, 1971; Fitzsimons, 1997). As the ice of the moraine melts, sediment elevation is reduced proportional to the initial thickness of the moraine and its debris content. Clark (1992) suggested that $30 \mathrm{~m}$ was a likely maximum for such subsidence, but did not provide a rationale for this value. Figure 3 shows that larger reductions in sediment elevation during deposition are possible, particularly since moraine elevations kilometers from the distal edge of the moraine are considered to have been equal to the ice-surface elevation (Clark, 1992).

To estimate the possible decrease in moraine elevation since deposition began, the average minimum thickness, $T_{\mathrm{m}}$, of the DML supraglacial sediment (Morgan Member) was estimated over $3-5 \mathrm{~km}$ intervals by measuring the relief on the Bemis Moraine associated with closed and semi-closed depressions (Fig. 3). The past thickness of the moraine, assuming that it was ice-cored, is $T_{\mathrm{m}}(1-p) / C_{\mathrm{d}}$, where $\mathrm{p}$ is the porosity of the sediment in the current moraine $(\sim 0.3)$ and $C_{\mathrm{d}}$ the mean volumetric debris fraction of the ice-cored moraine. The value of $C_{\mathrm{d}}$ may vary widely (Kirkbride, 1995). A reasonable value, $C_{\mathrm{d}}=0.15$, yields an ice-cored moraine elevation that ranges, depending upon location, from 25 to $100 \mathrm{~m}$ higher than the modern moraine. A lower debris concentration, $C_{\mathrm{d}}=0.05$, is also plausible and would result in 75$300 \mathrm{~m}$ of sediment subsidence during moraine deposition. Thus, we also reconstructed the lobe using $C_{\mathrm{d}}=0.15$ and $C_{\mathrm{d}}=0.05$, considering moraine subsidence resulting from the latter value as an upper bound. Further motivation for considering a higher terminal moraine comes from soil studies that indicate original relief of some moraines of the DML has been reduced by $65 \%$ due to slope processes (Burras and Scholtes, 1987).

The reconstruction using modern moraine elevations is shown in Figure 4a. The lobe is very thin, and similar in longitudinal profile to that determined by Clark (1992) (Fig. 4b). In contrast, if the Bemis Moraine were ice-cored, the reconstructions yield lobes that are thicker by factors about 2 and 3 for $C_{\mathrm{d}}=0.15$ and $C_{\mathrm{d}}=0.05$, respectively (Fig. $4 \mathrm{~b}$ ). These results indicate that modern moraine elevations may yield a significant underestimate of glacier thickness and surface slope.

From the reconstructed profiles, basal shear stress can be calculated. In the absence of side drag from valley walls or from adjacent slow-moving ice, a good assumption for the DML, the driving stress for glacier motion can be equated with the basal shear stress $\tau_{\mathrm{b}}$, given by $\tau_{\mathrm{b}}=\rho_{\mathrm{i}} g H \sin \alpha$, where $\rho_{\mathrm{i}}$ is the density of ice $\left(916 \mathrm{~kg} \mathrm{~m}^{-3}\right), g$ is the acceleration due to gravity, $H$ is the glacier thickness and $\alpha$ the surface slope. To minimize possible errors associated with longitudinal stress gradients, values of $\tau_{\mathrm{b}}$ were calculated over distances of $20 \mathrm{H}$ along the flowline (Paterson, 1994, p. 264).

If the Bemis Moraine were ice-cored, calculated shear stresses were up to seven times as large $(4-15 \mathrm{kPa})$ as those 

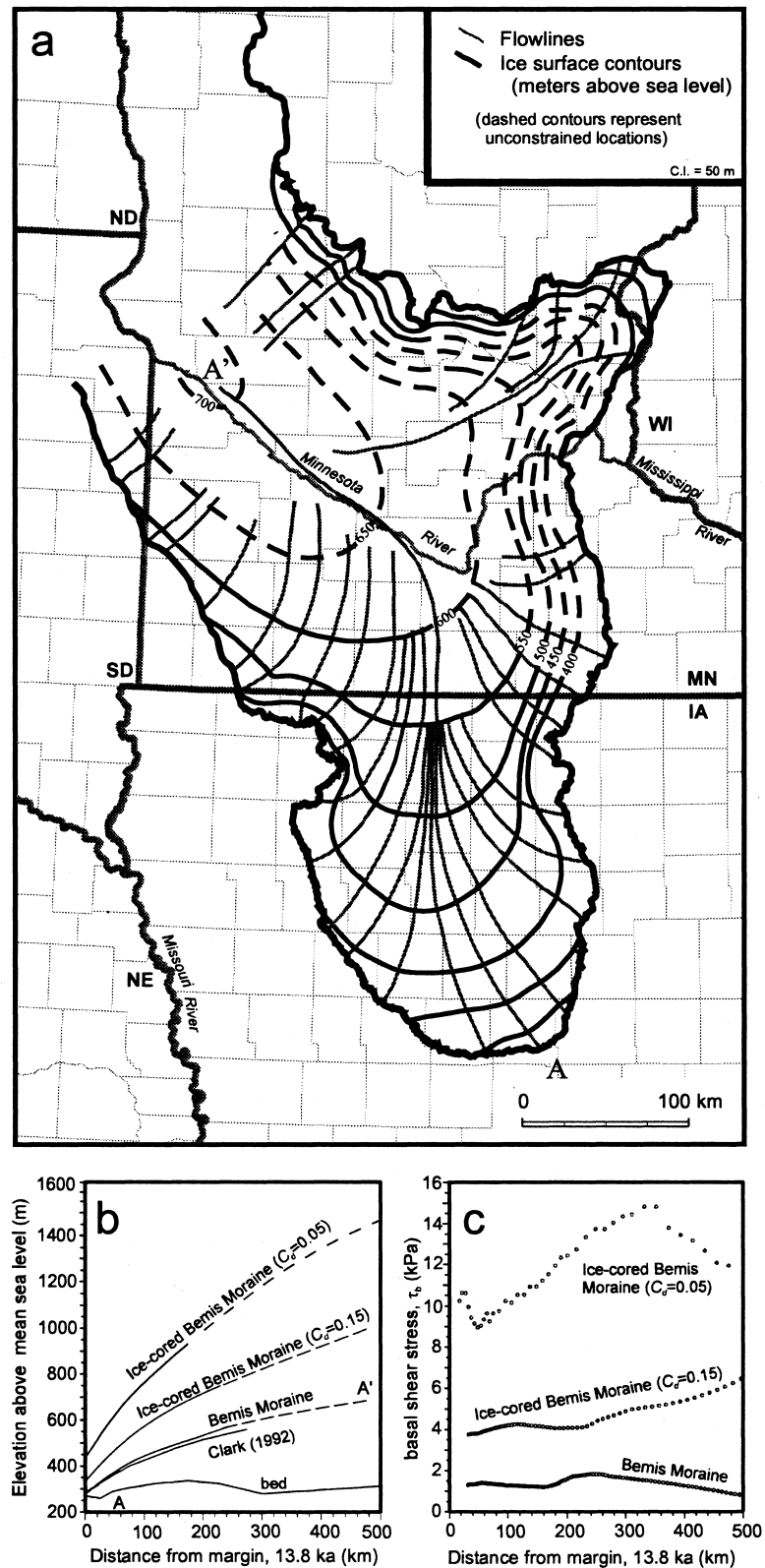

Fig. 4. (a) Reconstructed ice-surface morphology and flowlines for the DML, based on the present elevation of the Bemis Moraine. Flowline $A-A^{\prime}$ is the trace of the longitudinal icesurface profile shown in Figures $4 b$ and $5 a$. (b) Longitudinal ice-surface profiles for the DML compared with that of Clark (1992). (c) Basal shear stresses calculated every $20 \mathrm{H}$ for the three reconstructions shown in $(b)$.

determined using the modern moraine elevation (Fig. 4c). Nevertheless, given that an approximate average shear stress for glaciers is $50 \mathrm{kPa}$ (Paterson, 1994, p. 242), even the icecored moraine cases yield shear stresses that are small. Rapid movement of the DML under such shear stresses likely required that it was not frozen to its bed (e.g. Mickelson, 1987).

\section{BASAL WATER PRESSURE AND POTENTIOMETRIC SURFAGE}

High water pressure in the subglacial hydraulic system may have been responsible for the low basal shear stresses, as it is beneath some modern ice streams (Engelhardt and Kamb, 1997). In this section, lower bounds for the water pressure in this system and the elevation of the potentiometric surface are estimated from results of consolidation tests on intact specimens of the DML basal till and from the reconstructed ice thickness.

In a consolidation test, a confined, water-saturated soil specimen is subjected to incremental increases in axial stress. After each increase in stress, excess pore-water pressure is allowed to dissipate as the specimen contracts. Initial stress increments are small, resulting in mostly elastic deformation of the soil skeleton. At a sufficiently large stress, however, called the preconsolidation stress, the specimen begins to contract permanently. This stress, $P_{\mathrm{e}}^{\max }$, is inferred to have been the maximum effective stress (total normal stress minus pore pressure) on the till during glacier loading, assuming negligible sediment disturbance since deglaciation.

Intact specimens of the DML basal till were collected from 13 locations in Iowa and Minnesota, and consolidation tests yielded a value of $P_{\mathrm{e}}^{\max }$ at each location. Care was taken to sample only the basal till of the DML (Alden Member), rather than the supraglacial Morgan Member. The basal till was identified based on its distinct textural homogeneity and by measuring its dry density (Luttenegger and others, 1983). Radiocarbon ages from organic material at the base of this till indicate that is not older than 15500 years (Bettis and others, 1996), so no earlier glacier advance could have caused its overconsolidation. The Appendix describes the sampling procedure and data reduction. To avoid costly coring, specimens were collected from outcrops, all of which were above the water table when sampled. The specimens had thus dried since loading by the glacier, which can cause consolidation of fine-grained sediments and thereby yield overestimates of preconsolidation stress (Mickelson and others, 1979; Tulaczyk and others, 2001). Values of $P_{\mathrm{e}}^{\max }$ reported herein, therefore, are upper bounds for effective normal stresses on the bed during loading by the lobe, so actual effective normal stresses on the bed may have been lower.

Measured values of $P_{\mathrm{e}}^{\max }$ range from 125 to $300 \mathrm{kPa}$ (Table 1) and are consistent with unpublished consolidation data from the basal till of the DML (Kanwar and others, 1990, 1992). These values are relatively small, given that over the sampling area our reconstructions indicate total normal stresses on the bed generally greater than $1000 \mathrm{kPa}$. Apparently, pore-water pressure was sufficiently high in the till to support most of the glacier's weight. Similarly small values of $P_{\mathrm{e}}^{\mathrm{max}}$ have been measured in consolidation tests on other basal tills (e.g. Solheim and others, 1991; Sauer and others, 1993; Piotrowski and Kraus, 1997). Our values of $P_{\mathrm{e}}^{\max }$ are also comparable to the largest effective normal stresses calculated from measured water pressures beneath Whillans Ice Stream (Engelhardt and Kamb, 1997). Note that all measured values of $P_{\mathrm{e}}^{\max }$ at a given location exceed modern total normal stresses that result from sediment overburden (Table 1).

To estimate the water pressure at the ice/bed interface, we must account for the difference in water pressure there and that at depth in the bed where the till specimens were collected. If the saturated bulk density of the till is $\rho_{\mathrm{T}}(1600-$ $2000 \mathrm{~kg} \mathrm{~m}^{-3}$ ), then the minimum pore-water pressure, $P_{\mathrm{w}}^{\min }$, at depth $d_{\mathrm{T}}$ in the basal till is given by

$$
P_{\mathrm{w}}^{\min }=\rho_{\mathrm{i}} g H+\rho_{\mathrm{T}} g d_{\mathrm{T}}-P_{\mathrm{e}}^{\max },
$$

where the sum of the first two terms on the righthand side is the total normal stress. If it is assumed that there was not significant bed-normal ground-water flow through the till, then the minimum water pressure at the ice/bed interface, 

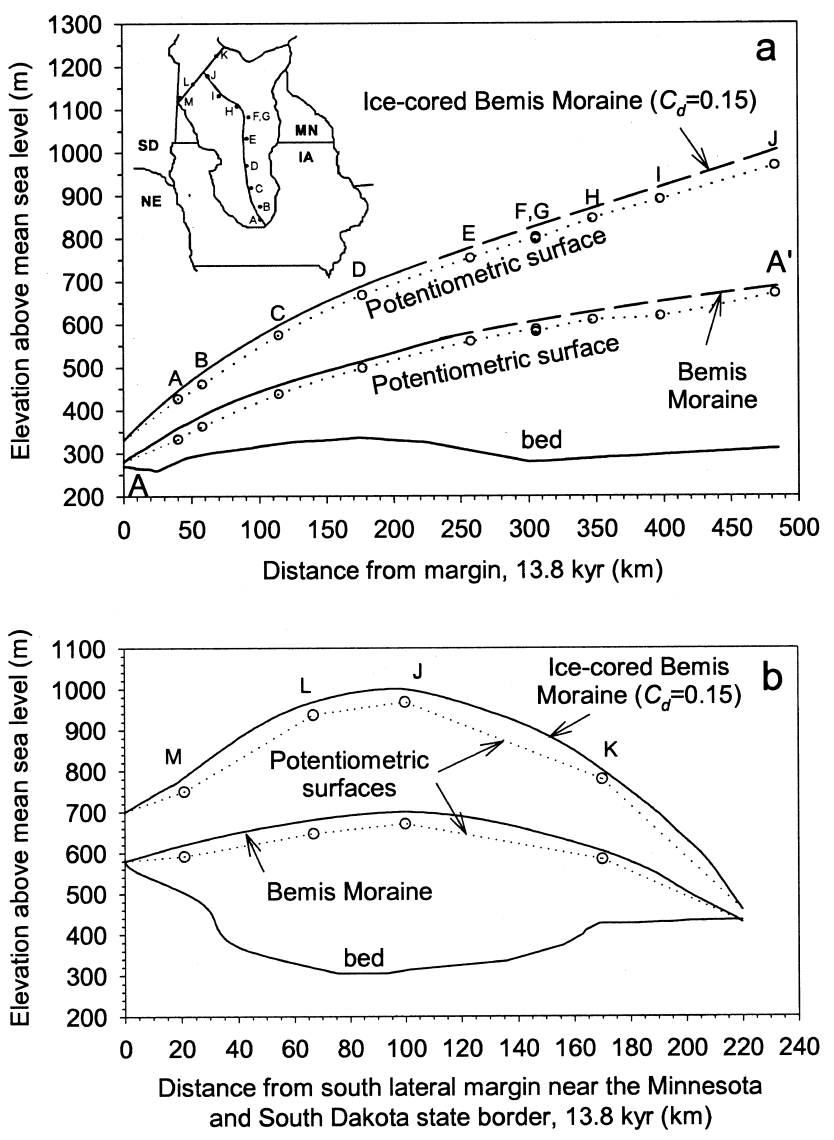

Fig. 5. Longitudinal (a) and transverse (b) potentiometric surfaces of the DML. Letters $A-\mathcal{F}$ are sampling locations projected onto the longitudinal transect $A-A^{\prime}$ (Fig. 2 and inset map), whereas letters $M, L, \mathcal{F}$ and $K$ are sampling locations projected onto a transverse transect (inset map).

$P_{\mathrm{wi}}^{\min }$, was less than $P_{\mathrm{w}}^{\min }$ by an amount equal to the change in hydrostatic pressure over $d_{\mathrm{T}}$. Thus,

$$
P_{\mathrm{wi}}^{\min }=P_{\mathrm{w}}^{\min }-\rho_{\mathrm{w}} g d_{\mathrm{T}}=\rho_{\mathrm{i}} g H+\left(\rho_{\mathrm{T}}-\rho_{\mathrm{w}}\right) g d_{\mathrm{T}}-P_{\mathrm{e}}^{\max },
$$

where $\rho_{\mathrm{w}}$ is the density of water. Note that in the case of downward ground-water flow - a likely possibility - the product $\rho_{\mathrm{w}} g d_{\mathrm{T}}$ would overestimate the change in pore-water pressure with depth in the till. Thus, even with downward ground-water flow, the water pressure at the ice/bed interface would not have been less than $P_{\text {wi }}^{\min }$ as given by Equation (2).

From values of $P_{\mathrm{e}}^{\max }$ and from ice thicknesses determined from the reconstructions of the lobe, minimum water pressures at the ice/till interface (Table 1) are calculated using Equation (2). The corresponding potentiometric surfaces are plotted in Figure 5 on longitudinal and transverse surface profiles of the DML. Average ratios of $P_{\mathrm{wi}}^{\min }$ to $\rho_{\mathrm{i}} g H$ are 0.91 and 0.95 for reconstructions based on the elevations of modern and ice-cored moraines, respectively, assuming $C_{\mathrm{d}}=0.15$ in the latter case, which we consider to be the more plausible of the two ice-cored moraines considered. The DML was therefore nearly floating on its bed. The high basal water pressure probably rules out a drainage system consisting of tunnels cut into ice (Röthlisberger, 1972). Channels cut into the bed (Walder and Fowler, 1994) fed by a distributed water system in intervening zones (e.g. Engelhardt and Kamb, 1997) would support higher water pressures more like those indicated herein.

\section{FLOW MECHANISMS}

The low basal shear stresses and effective normal stresses at the bed of the DML indicate that little of its motion was by internal ice deformation. The velocity due to deformation, averaged over the ice thickness, is $U_{\mathrm{i}}=2 A E \tau_{\mathrm{b}}^{n} H /(n+2)$, where $A$ is an ice-creep parameter, inversely proportional to the effective ice viscosity, $E$ is an enhancement factor for soft Wisconsin-age ice, and $n$ is the stress exponent in the flow relation for ice (Paterson, 1994). Using maximum values of $\tau_{\mathrm{b}}$ and $H$ (ice-cored Bemis Moraine, $C_{\mathrm{d}}=0.05$ ) to maximize $U_{\mathrm{i}}$ and reasonable values of $A\left(7 \times 10^{-15} \mathrm{kPa}^{-3} \mathrm{~s}^{-1}\right), n$ (3), and $E$ (2.5) (Paterson, 1994), $U_{\mathrm{i}}$ is $<1.0 \mathrm{ma}^{-1}$. This upper limit is approximately three orders of magnitude less than inferred advance rates of the DML (Clayton and Moran, 1982). Expected variability of $A$ and $E$ (Paterson, 1994) falls well short of accounting for this difference in speed. Thus, motion likely occurred primarily by some combination of sliding, plowing and bed deformation. Next we attempt to determine with theory and field observations whether ice decoupled from the bed by plowing and sliding or whether the bed sheared pervasively.

\section{Model calculations}

\section{Model description}

The model of Iverson (1999) is used to estimate the shear strength of the ice-till interface for comparison with the strength of the DML basal till over the relevant range of effective normal stress. If, for example, the interface strength exceeded the bed shear strength, the ice would have been coupled to the bed sufficiently to shear it at a stress equal to the till shear strength. If the converse were true, motion would have occurred at or near the glacier sole by sliding and plowing. An abbreviated description of the model, which is built partly upon aspects of earlier models (Brown and others, 1987; Alley, 1989), is given herein.

Particles at the bed surface that protrude into the glacier sole provide the roughness that couples ice to the bed (Brown and others, 1987; Alley, 1989; Tulaczyk, 1999). The shear stress supported by these particles depends on whether sliding ice exerts a sufficient bed-parallel drag on them to cause them to plow through the bed. If particles plow, the shear stress they support, $\tau_{\mathrm{p}}$, depends on the till strength and is given by

$$
\tau_{\mathrm{p}}=\frac{1}{2+N_{\mathrm{p}} k}\left[N_{\mathrm{p}}\left(P_{\mathrm{e}}+\frac{c}{\tan \phi}\right)-\frac{c}{\tan \phi}\right],
$$

where $P_{\mathrm{e}}$ is the ambient effective normal stress at the ice-till interface, $\phi$ and $c$ are the friction angle and cohesion of the till, respectively, $N_{\mathrm{F}}$ is a bearing-capacity factor that depends on $\phi$, and $k$ is a pressure-shadow factor that accounts for the less-than-ambient ice pressure expected in the lee of particles (Iverson, 1999). If particles do not plow, the shear stress on them is controlled by the classical mechanisms of glacier sliding: regelation and enhanced ice deformation. Ice slides primarily by regelation (melting and refreezing) past small particles and primarily by ice deformation past large particles. The transition particle size for which both mechanisms contribute equally depends on the sliding speed but ranges from $\sim 5$ to $\sim 100 \mathrm{~mm}$ (Lliboutry, 1979; Brown and others, 1987). A complication is that water-filled cavities may form in the lee of particles. Particles with and without such cavities support shear stresses, $\tau_{\mathrm{c}}$ and $\tau_{\mathrm{s}}$, respectively, which are 
Table 1. Results of consolidation experiments

\begin{tabular}{|c|c|c|c|c|c|c|c|c|c|c|c|c|c|c|}
\hline \multirow[t]{2}{*}{$\begin{array}{l}\text { Nearest town to } \\
\text { sample location }\end{array}$} & \multirow[t]{2}{*}{$\begin{array}{l}\text { Location } \\
\text { in Fig. } 2\end{array}$} & $P_{\mathrm{e}}^{\max }$ & $\begin{array}{c}\text { Depth in } \\
\text { basal till } \\
d_{\mathrm{T}}\end{array}$ & $\begin{array}{c}\text { Modern } \\
\text { total } \\
\text { overburden } \\
\text { stress }\end{array}$ & $\begin{array}{c}B M \\
H\end{array}$ & $\begin{array}{l}\text { Ice-cored } \\
B M, H^{1}\end{array}$ & $\begin{array}{c}B M, \\
\rho_{\mathrm{i}} g H\end{array}$ & $\begin{array}{c}\text { Ice-cored } \\
B M, \\
\rho_{\mathrm{i}} g H^{1}\end{array}$ & $\begin{array}{l}B M \\
P_{\mathrm{wi}}^{\min }\end{array}$ & $\begin{array}{c}\text { Ice-cored } \\
B M, \\
P_{\mathrm{wi}}^{\min ^{1}}\end{array}$ & $\begin{array}{c}B M, \\
P_{\mathrm{wi}}^{\mathrm{min}} / \\
\rho_{\mathrm{w}} g\end{array}$ & $\begin{array}{c}\text { Ice-cored } \\
B M, P_{\mathrm{wi}}^{\min } / \\
\rho_{\mathrm{w}} g^{1}\end{array}$ & $\begin{array}{c}B M, \\
P_{\mathrm{wi}}^{\min } / \\
\rho_{\mathrm{i}} g H\end{array}$ & $\begin{array}{c}\text { Ice-cored } \\
B M, P_{\mathrm{wi}}^{\min } / \\
\rho_{\mathrm{i}} g H^{1}\end{array}$ \\
\hline & & $\mathrm{kPa}$ & $\mathrm{m}$ & $\mathrm{kPa}$ & $\mathrm{m}$ & $\mathrm{m}$ & $\mathrm{kPa}$ & $\mathrm{kPa}$ & $\mathrm{kPa}$ & $\mathrm{kPa}$ & m.a.s.l. & m.a.s.l. & & \\
\hline Des Moines, IA & $\mathrm{A}$ & 170 & 5.0 & 85 & 79 & 175 & 710 & 1573 & 576 & 1438 & 333 & 427 & 0.81 & 0.92 \\
\hline Fort Dodge, IA & $\mathrm{C}$ & 200 & 4.0 & 69 & 135 & 275 & 1213 & 2471 & 1043 & 2301 & 438 & 575 & 0.86 & 0.93 \\
\hline Algona, IA & $\mathrm{D}$ & 125 & 2.0 & 31 & 178 & 352 & 1600 & 3163 & 1486 & 3050 & 498 & 668 & 0.93 & 0.96 \\
\hline Blue Earth, MN & $\mathrm{E}$ & 150 & 3.0 & 49 & 276 & 474 & 2480 & 4259 & 2350 & 4129 & 560 & 754 & 0.95 & 0.97 \\
\hline Mankato, MN & $\mathrm{F}$ & 150 & 3.0 & 48 & 327 & 547 & 2938 & 4915 & 2807 & 4784 & 586 & 801 & 0.96 & 0.97 \\
\hline Mankato, MN & G & 200 & 6.0 & 96 & 327 & 547 & 2938 & 4915 & 2776 & 4752 & 582 & 798 & 0.95 & 0.97 \\
\hline New Ulm, MN & $\mathrm{H}$ & 120 & 1.8 & 29 & 341 & 582 & 3064 & 5230 & 2956 & 5122 & 610 & 846 & 0.97 & 0.98 \\
\hline Morton, MN & I & 300 & 10.0 & 160 & 356 & 622 & 3194 & 5589 & 2948 & 5351 & 619 & 879 & 0.93 & 0.96 \\
\hline Big Bend City, MN & $\mathrm{J}$ & 200 & 1.5 & 24 & 365 & 688 & 3460 & 6182 & 3269 & 5992 & 671 & 968 & 0.95 & 0.97 \\
\hline Providence, MN & $\mathrm{L}$ & 175 & 3.0 & 49 & 367 & 663 & 3298 & 5958 & 3142 & 5802 & 647 & 937 & 0.95 & 0.97 \\
\hline Hendricks, MN & M & 225 & 3.0 & 57 & 228 & 390 & 2049 & 3505 & 1852 & 3308 & 592 & 750 & 0.90 & 0.94 \\
\hline
\end{tabular}

Note: BM, Bemis Moraine. ${ }^{1} C_{\mathrm{d}}=0.15$.

related to $P_{\mathrm{e}}$, the sliding speed, $U_{\mathrm{s}}$, and particle radius, $R$, through the expressions (Lliboutry, 1979):

$$
\begin{aligned}
U_{\mathrm{s}} & =\frac{A_{1} \tau_{\mathrm{s}}^{3} R+C \tau_{\mathrm{s}}}{R} \\
\tau_{\mathrm{c}} & =\frac{1}{2}\left(\tau_{\mathrm{s}}+P_{\mathrm{e}}\right),
\end{aligned}
$$

where $A_{1}$ is an ice-creep constant, and $C$ is a constant that depends on the thermal properties of the ice and particles. Cavities are expected in the lee of particles near the transition size, which are not accommodated easily by either regelation or enhanced ice deformation. The radii of the largest and smallest particles for which cavities are expected are given by

$$
R=\frac{U_{\mathrm{s}} \pm\left(U_{\mathrm{s}}^{2}-4 A_{1} C P_{\mathrm{e}}^{4}\right)^{\frac{1}{2}}}{2 A_{1} P_{\mathrm{e}}^{3}}
$$

(Iverson, 1999).

Estimating the shear strength of the ice-till interface from values of $P_{\mathrm{e}}$ and $U_{\mathrm{s}}$ requires that shear stresses supported by individual particles of various sizes at the bed surface be calculated. To do so, for each size class $i$ of particles, we determine either $\tau_{\mathrm{s}}$ (Equation (4)) or $\tau_{\mathrm{c}}$ (Equation (5)), depending upon whether particles of that size should have leeward cavities, as given by Equation (6). This value is then compared with the value of $\tau_{\mathrm{p}}$ (Equation (3)). If $\tau_{\mathrm{s}}\left(\right.$ or $\left.\tau_{\mathrm{c}}\right)>\tau_{\mathrm{p}}$, ice will exert sufficient drag on the particle to cause it to plow, so the

Table 2. Model parameters

\begin{tabular}{lcc}
\hline Parameter & Symbol & Value \\
\hline Sliding speed & $U_{\mathrm{s}}$ & $440 \mathrm{~m} \mathrm{a}^{-1}$ \\
Ice-creep parameter & $A$ & $1.2 \times 10^{-25} \mathrm{~Pa}^{-3} \mathrm{~s}^{-1}$ \\
Regelation parameter & $C$ & $2.8 \times 10^{-15} \mathrm{~m}^{2} \mathrm{~Pa}^{-1} \mathrm{~s}^{-1}$ \\
Ultimate friction angle & $\phi_{\mathrm{u}}$ & $18.5^{\circ}$ \\
Cohesion intercept & $c_{\mathrm{i}}$ & $0.0 \mathrm{kPa}$ \\
Angle between slip surfaces in till and & $\beta$ & $15^{\circ}$ \\
$\quad$ normal to the bed & $\beta$ & 0.1 \\
Pressure-shadow factor & $k$ & varies $(0-300 \mathrm{kPa})$ \\
Effective pressure & $P_{\mathrm{e}}$ & 2.96 \\
Water-layer thickness & - & varies $(0.001-10 \mathrm{~mm})$ \\
Fractal dimension & - & $0.5 \mathrm{~m}$ \\
Upper fractal limit & $R_{\mathrm{u}}$ & \\
& &
\end{tabular}

shear stress on that size class, $\tau_{i}$, will be equal to $\tau_{\mathrm{p}}$. If $\tau_{\mathrm{s}}$ (or $\tau_{\mathrm{c}}$ ) $\leq \tau_{\mathrm{p}}$, the particle will not plow, so $\tau_{i}$ will be equal to either $\tau_{\mathrm{s}}$ or $\tau_{\mathrm{c}}$, depending upon whether leeward cavities are expected. For each size class $i$, the value of $\tau_{i}$ is determined in this way and multiplied by the fractional area of the bed occupied by that size class, $A_{i f}$. Summing these products for all size classes yields the shear strength of the ice/till interface that results from sliding and plowing, $\tau_{\mathrm{sp}}$, for specified values of $P_{\mathrm{e}}$ and $U_{\mathrm{s}}$ (Brown and others, 1987; Iverson, 1999):

$$
\tau_{\mathrm{sp}}=\sum_{i=1}^{m} \tau_{i} A_{i \mathrm{f}} .
$$

Values of $A_{i f}$ depend on the size distribution of grains at the bed surface, which is assumed to be equivalent to the grainsize distribution of the till. $A_{i f}$ is given by

$$
A_{i \mathrm{f}}=\frac{\left(R_{i+1}{ }^{3-d}-R_{i}{ }^{3-d}\right)(1-p)}{R_{\mathrm{u}}{ }^{3-d}},
$$

where $d$ is the fractal dimension of the grain-size distribution, $p$ is the till porosity, and $R_{\mathrm{u}}$ is the upper fractal limit, equal to the radii of the largest particles that contribute to the bed roughness (Iverson, 1999).

A thin water layer of non-uniform thickness separates basal ice from the bed (Brown and others, 1987; Alley, 1989; Tulaczyk, 1999), regardless of the substrate hydraulic permeability. The mean thickness of this layer, which depends on the extent of cavity development in the lee of particles (Iverson, 1999), is an important input to the model because particles with radii smaller than this thickness will not contribute to the interface strength. Thus, these particles are not included in the summation of Equation (7).

A final assumption is that sliding velocity does not depend on effective normal stress. Although there is good evidence that these parameters are correlated for some valley glaciers, data from Whillans Ice Stream indicate that $U_{\mathrm{s}}$ does not vary significantly with changes in $P_{\mathrm{e}}$ (Engelhardt and Kamb, 1997). As discussed subsequently, model results are very insensitive to variations in $U_{\mathrm{s}}$ over the range of values that likely bracket the speed of the DML, so the significance of assuming that $U_{\mathrm{s}}$ is independent of $P_{\mathrm{e}}$ is not great.

\section{Parameter selection}

To estimate the strength of the ice/till interface with this 

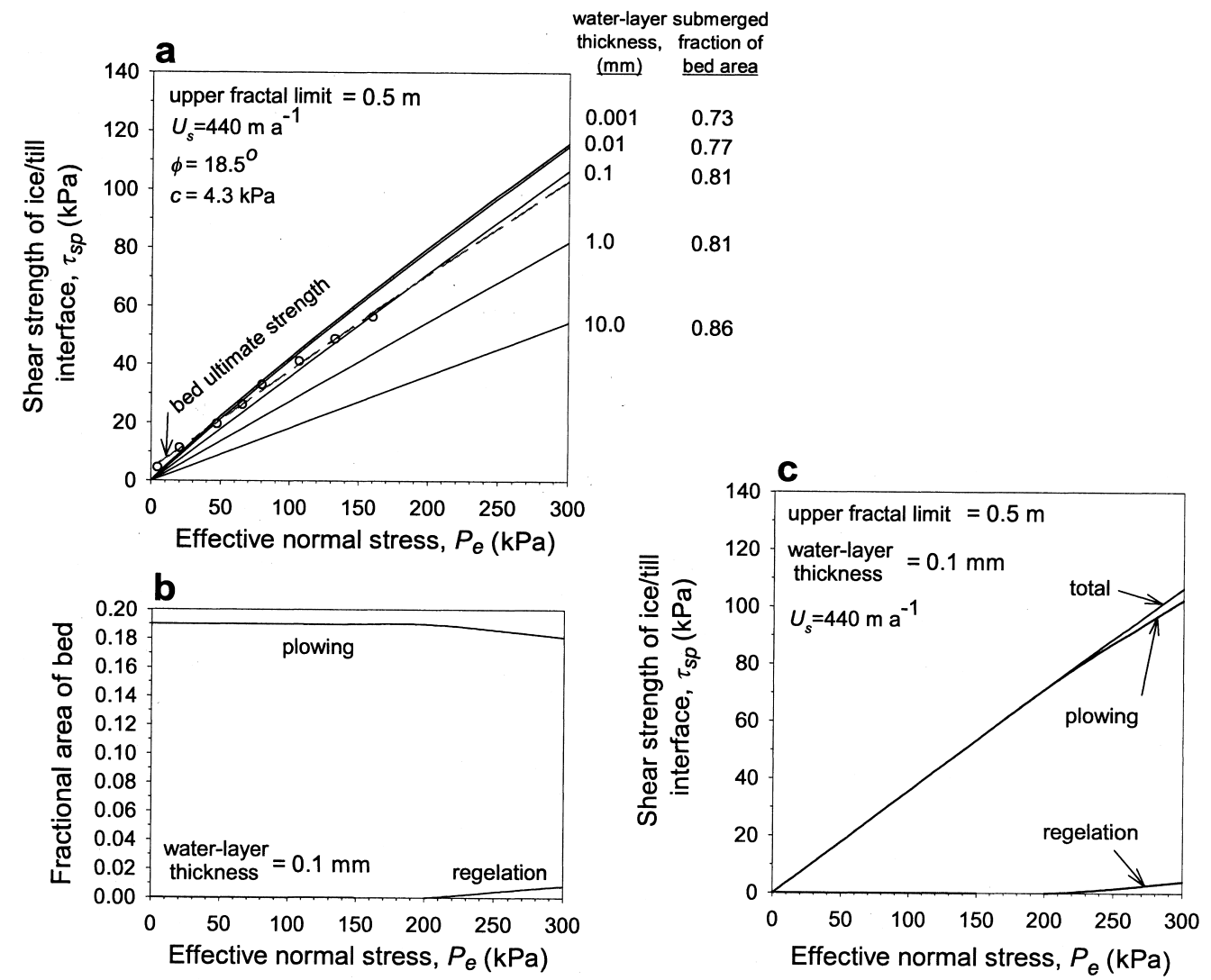

Fig. 6. (a) Calculated values of $\tau_{\mathrm{sp}}$ as a function of effective normal stress for various water-layer thicknesses. The steady-state shear strength (ultimate strength) of the DML basal till is also shown. (b) Fractional area of the bed occupied by plowing particles and by stationary particles accommodated by regelation for a water-layer thickness of $0.1 \mathrm{~mm}$. (c) Calculated values of $\tau_{\mathrm{sp}}$ as a function of effective normal stress. The value of $\tau_{\mathrm{sp}}$ has been divided into its two components: that supported by plowing particles and that supported by stationary particles accommodated by regelation.

model, the physical properties of the ice and sediment, the grain-size distribution, the sliding speed, the effective normal stress and the water-layer thickness must be specified. Values of these variables used in the calculation are summarized in Table 2. The steady-state friction angle of the DML basal till was determined in a drained ring-shear test (Hooyer, 1999) following the procedure outlined by Iverson and others (1997, 1998). These tests yielded $\phi=18.5^{\circ}$, in general agreement with values for some other clay-rich tills (Tika and others, 1996; Iverson and others, 1998). The bearing-capacity factor that is indicated by this friction angle is 4.6 (Iverson, 1999, equation (13)). Cohesion is assumed to be zero during steady deformation (e.g. Skempton, 1985).

Parameters for the ice include the regelation parameter, $C$, and the ice-creep parameter, $A_{1}$. These are taken to be $2.8 \times 10^{-15} \mathrm{~m}^{2} \mathrm{~Pa}^{-1} \mathrm{~s}^{-1}$ and $1.2 \times 10^{-25} \mathrm{~Pa}^{-3} \mathrm{~s}^{-1}$, respectively, and are appropriate values for clean, temperate ice (Lliboutry, 1979). The pressure-shadow factor, $k$, is assumed to be 0.1 , based on the analysis of Brown and others (1987) for flow dominated by regelation. As discussed subsequently, regelation rather than enhanced creep of ice is the primary mechanism of flow past particles too small to plow through the bed.

Particle-size analysis of the DML basal till yielded a fractal dimension of 2.96 (Hooyer, 1999). We assume that this value can be extrapolated to grain-sizes larger than those measured. The upper fractal limit is taken to be the radius of the largest boulder observed at 25 outcrops. This radius is $\sim 0.5 \mathrm{~m}$, although several other values are also considered to assess the sensitivity of the results to this variable.

The sliding speed of the DML is unknown, although according to the leading radiocarbon chronology the average rate of marginal advance and retreat was about $2000 \mathrm{~m} \mathrm{a}^{-1}$ (Clayton and Moran, 1982; Clayton and others 1985). Correcting this chronology for variable atmospheric production of $\mathrm{C}^{14}$ (Stuiver and others, 1998) results in a reduced rate of advance and retreat of $1700 \mathrm{~m} \mathrm{a}^{-1}$. We choose a more conservative value, $440 \mathrm{~m} \mathrm{a}^{-1}$, equal to that of Whillans Ice Stream (Engelhardt and Kamb, 1997), but also consider other values.

A range of values of effective normal stress is considered based on the results of consolidation tests (Table 1). These tests yielded maximum values of effective normal stress, and hence pore-water pressures in the till could have been higher than those indicated by these tests. Therefore, effective stresses of 0-300 $\mathrm{kPa}$ are considered.

The thickness of the water layer at the ice-till contact has been inferred for various modern and past glaciers (Alley, 1989; Engelhardt and Kamb, 1997; Hooke and others, 1997; Iverson, 1999; Piotrowski and Tulaczyk, 1999) but is not well known and probably highly variable. We consider various values between 0.001 and $10.0 \mathrm{~mm}$.

\section{Model results and discussion}

In Figure 6a the calculated shear strength of the ice/bed interface is plotted as a function of effective normal stress for several water-layer thicknesses. The shear strength of the interface is smaller for thicker water layers, owing to greater ice/bed separation. For example, an increase in water-layer thickness from $0.1 \mathrm{~mm}$ to $10.0 \mathrm{~mm}$ reduces the interface strength by about $50 \%$. These results, when compared to the shear strength of the till determined in ring-shear tests (bed ultimate strength; Fig. 6a), indicate that the water-layer thickness would have needed to be $<\sim 0.1 \mathrm{~mm}$ for $\tau_{\text {sp }}$ to exceed the 


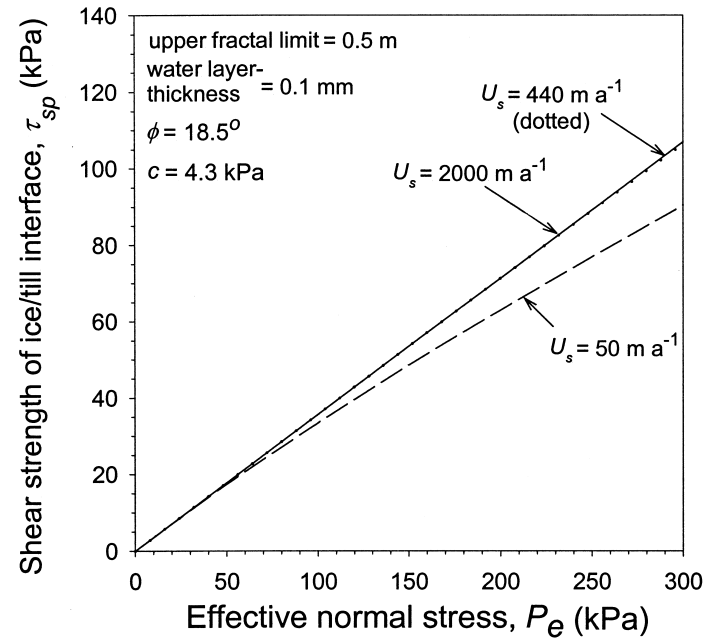

Fig. 7. Calculated values of $\tau_{\mathrm{sp}}$ as a function of effective normal stress for various values of sliding speed, assuming a water-layer thickness of $0.1 \mathrm{~mm}$.

till shear strength. In that case, the bed would have sheared at a stress equal to the bed shear strength. Based on borehole studies, a water-layer thickness of $\sim 0.1 \mathrm{~mm}$ has been suggested for Whillans Ice Stream (Engelhardt and Kamb, 1997). However, Alley and others (1987) suggested a minimum water-layer thickness an order of magnitude larger than this. Furthermore, modeling results fit to data collected from Storglaciären indicate a water-layer thickness of one to several centimeters (Iverson, 1999). A similarly thick water layer of 5-35 $\mathrm{mm}$ has been suggested based on the thickness of sand stringers in a Pleistocene basal till in northwest Germany (Piotrowski and Tulaczyk, 1999). Thus, it is not clear from these calculations that the bed sheared at depth. Instead, the weight of evidence seems to point, albeit with significant uncertainty, toward water layers thicker than $0.1 \mathrm{~mm}$ and hence to decoupling of ice from the bed.

Plowing of particles through the bed, rather than regelation or ice creep, limits the shear strength of the ice/bed interface (Fig. 6b). At effective normal stresses less than $200 \mathrm{kPa}$, all particles in contact with ice plow. These particles cover about $19 \%$ of the bed in the case of a water layer $0.1 \mathrm{~mm}$ thick; smaller particles are submerged in the water layer. At effective normal stresses greater than $200 \mathrm{kPa}$, the smallest particles that plow at lower effective normal stresses do not plow because the till is stronger. The shear stress supported by these particles is determined by regelation. Enhanced ice deformation does not limit the shear stress on particles of any size because those particles large enough to be accommodated by ice deformation plow through the bed for the range of effective normal stress considered. The contributions of plowing and regelation to the interface strength are shown in Figure 6c.

Increases in sliding speed have little effect on these results. If sliding speed is increased a factor of $\sim 4$ to $2000 \mathrm{~m} \mathrm{a}^{-1}$, the change in interface strength is negligible (Fig. 7), since plowing is the dominant flow mechanism at both the lower and higher sliding speeds, and shear stresses supported by plowing particles are independent of sliding speed. In contrast, at a much lower sliding speed of $50 \mathrm{~m} \mathrm{a}^{-1}$, the interface strength is reduced (Fig. 7). In this case, fewer particles plow; those that do not plow are accommodated easily by regelation and thus support shear stresses commensurate with the smaller sliding speed.

Upper fractal limits (radii of the largest boulders consid-

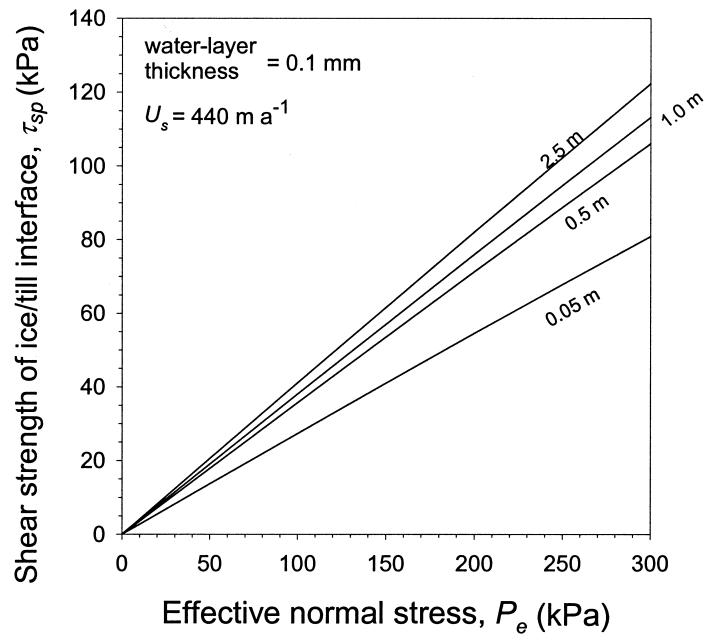

Fig. 8. Calculated values of $\tau_{\mathrm{sp}}$ as a function of effective normal stress for various values of the upper fractal limit of the grain-size distribution, assuming a water-layer thickness of $0.1 \mathrm{~mm}$.

ered) both smaller and larger than $0.5 \mathrm{~m}$ are considered in Figure 8. If very large boulders are included as part of the grain-size distribution, they strengthen the interface appreciably. However, because such boulders are so uncommon, the length scale over which the calculation applies is much greater than the till thickness if such boulders are considered. For example, Equation (8) indicates that if $R_{\mathrm{u}}=$ $2.5 \mathrm{~m}$, boulders with radii $2.0-2.5 \mathrm{~m}$ will occur in a strip of unit width less than once every $1700 \mathrm{~m}$. In contrast, if $R_{\mathrm{u}}=$ $0.5 \mathrm{~m}$, boulders with radii $0.1-0.5 \mathrm{~m}$ will occur about every $5 \mathrm{~m}$. Thus, considering boulders that are much larger than $0.5 \mathrm{~m}$ does not provide a physically meaningful estimate of the local strength of the ice-till interface.

Although our calculations are sensitive to a poorly known parameter - the thickness of the water layer that divided ice from the till bed - they indicate that plowing may have occurred easily enough at the bed surface to prevent the bed from pervasively shearing at depth. This hypothesis is now tested by comparing the alignment of elongate clasts in the DML basal till with that developed by shearing of till in the laboratory.

\section{Clast fabric of the DML basal till}

We have used a ring-shear device that deforms a large till specimen to study the alignment of isolated, elongate particles (6-16 mm long axes) as a function of shear strain (Hooyer and Iverson, 2000). Our results indicate that particles rotate into the shear plane and generally remain there to high shear strains (up to 475), resulting in a strong shearparallel fabric, regardless of the sizes, shapes and initial orientations of particles. Elongate particles generally remain in the shear plane, rather than orbit through it (e.g. Jeffery, 1922), due to slip between particles and till matrix. $S_{1}$ eigenvalues (Mark, 1973), indicative of fabric strength $\left(S_{1}=\right.$ 1.0, perfect alignment; $S_{1}=0.33$, random alignment), were high $(0.78-0.87)$, and particles attained a steady alignment at shear strains of $\sim 2.0$. If subglacial shear strain is pervasive and approximates simple shear, this result should be applicable to field settings, since evidence for subglacial slip between clasts and till matrix is ample (e.g. Benn and Evans, 1996). Thus, basal tills with weak fabrics have probably not been sheared to the high strains $(\gg 2.0)$ required to 

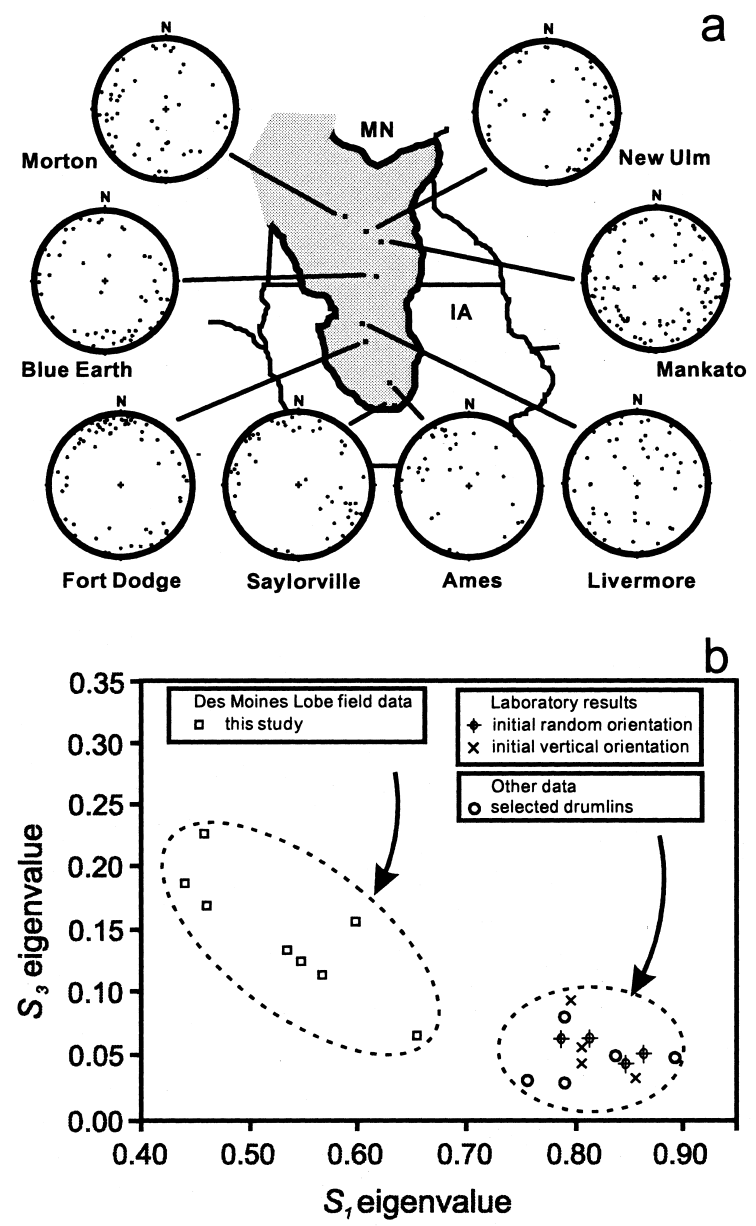

Fig. 9. (a) Clast fabric stereograms for the DML basal till at various locations. (b) $S_{1}$ vs $S_{3}$ eigenvalues for the DML basal till, for till deformed in ring-shear tests (Hooyer and Iverson, 2000), and for till of selected drumlins (Evenson, 1971; Krüger and Thomsen, 1984; Stanford and Mickelson, 1985).

account for significant glacier motion, although fabric disruption by another process or slip along widely spaced, discrete surfaces in the bed cannot be ruled out. In contrast, basal tills with a strong fabric parallel to the shearing direction may have been sheared pervasively to high strains.

Bennet and others (1999) have rightly questioned the use of clast fabric in discriminating between glacial-sediment facies. The goal here, however, is not to discriminate between facies but to address whether the bed has been sheared sufficiently to induce a strong fabric (shear strain $>2$ ). The fabric data compiled from field studies by Bennet and others (1999) do not allow an evaluation of the correlation between fabric strength and shear-strain magnitude because strain magnitude is seldom known with certainty in field studies.

Clast fabrics from the DML basal till were measured at a number of locations across Minnesota and Iowa (Fig. 9a). As with sampling for preconsolidation tests, basal till was identified based on its textural homogeneity and density. Measured dry densities at the sites of the fabric measurements fell within the range for basal tills in Iowa determined by Luttenegger and others (1983). Fabric measurements in till that did not meet this density criterion were excluded from consideration. In all cases, the till units where fabric was measured were massive, displaying neither clear signs of bed deformation nor preservation of primary structures that might preclude significant deformation (Clayton and others, 1989; Piotrowski and others, 2001). Fabric was measured by exposing a vertical cut along an outcrop surface and measuring the trend and plunge of 25-100 gravel-sized clasts over outcrop areas of $1-5 \mathrm{~m}^{2}$. Measurements over smaller areas were not possible owing to the low density of clasts sufficiently large and elongate to measure accurately. Thus, zones of local deformation, such as those that would result from plowing at the glacier sole, could not be resolved with this technique. Most fabrics were measured in unoxidized till below any visible soil horizons. Only prolate clasts that had aspect ratios $>1.5$ were measured. Fabric was evaluated using the method of Mark (1973) to calculate eigenvectors and corresponding eigenvalues. The eigenvalues $S_{1}, S_{2}$ and $S_{3}$ represent the degree of clustering around each of the axes of the eigenvectors, $V_{1}, V_{2}$ and $V_{3}$, respectively.

Measured fabrics are weak, with a mean $S_{1}$ value of 0.54 (Table 3). Plotting $S_{3}$ against $S_{1}$ for each site indicates that these fabrics are considerably weaker than those produced by till deformation in the laboratory (mean $S_{1}=0.82$ ) and not as strong as those of selected drumlins where a mobile till bed seems likely (Fig. 9b). Interpretation of these data, however, is complicated by unpublished measurements of basal-till fabric from three sites within end moraines in Iowa made by Kemmis (1991; personal communication from T. J. Kemmis, 2002). At these sites, $S_{1}=0.68-0.91$, indicating generally stronger fabrics than those measured in this study. Kemmis did not attribute the strong fabric to bed deformation at two of his sites due to stratigraphic evidence (sharp contacts and preserved sand lenses) and geomorphic relations (convex upper contact that mimicked the hummocky surface topography, suggestive of basal melt-out from stagnant ice) (Kemmis and others, 1981; Kemmis, 1991). At one site (55 Algona-2; Kemmis, 1991), however, where the mean $S_{1}$ value was 0.82 , no evidence seemed to preclude deformation of the bed. Thus, although fabric data from the majority of locations studied indicate that, if the bed of the DML was sheared pervasively, shear strain was likely less than $\sim 2.0$, fabrics at some locations are sufficiently strong to be consistent with significant pervasive shear of the bed.

\section{CONGLUSIONS}

Although our reconstructions corroborate previous conclusions (Mathews, 1974; Clark, 1992; Brevik, 2000) that the DML was thin, reconstructions assuming that its terminal moraine was ice-cored result in up to a three-fold increase in glacier thickness. Calculated basal shear stresses are as much as 3.5 times larger than the largest value thought to be reasonable by Clark (1992) (4.3 kPa). If moraines of other

Table 3. Fabric results for the DML till

\begin{tabular}{|c|c|c|c|c|c|}
\hline \multirow[t]{3}{*}{ Location } & \multirow{3}{*}{$\begin{array}{c}\text { Number of } \\
\text { clasts }\end{array}$} & \multicolumn{2}{|c|}{ Eigenvalues } & \multicolumn{2}{|c|}{$V 1$} \\
\hline & & $S_{1}$ & $S_{3}$ & Trend & Plunge \\
\hline & & & & 。 & 。 \\
\hline Morton, MN & 50 & 0.44 & 0.18 & 263.2 & 19.8 \\
\hline New Ulm, MN & 50 & 0.54 & 0.12 & 124.2 & 5.0 \\
\hline Mankato, MN & 95 & 0.46 & 0.17 & 79.4 & 1.1 \\
\hline Blue Earth, MN & 50 & 0.54 & 0.14 & 142.6 & 6.8 \\
\hline Livermore, IA & 52 & 0.46 & 0.23 & 22.0 & 8.5 \\
\hline Fort Dodge, IA & 73 & 0.67 & 0.06 & 344.4 & 6.1 \\
\hline Ames, IA & 36 & 0.60 & 0.16 & 317.5 & 19.0 \\
\hline Saylorville, IA & 50 & 0.58 & 0.11 & 134.5 & 1.6 \\
\hline
\end{tabular}


lobes of the Laurentide ice sheet were ice-cored, then those ice lobes were also thicker than reconstructions indicate.

Calculated basal shear stresses, together with the radiocarbon chronology that provides evidence of rapid glacier motion, indicate that the lobe was likely not frozen to its bed and that movement was focused at the base of the lobe with little internal ice deformation. The well-lubricated base of the DML is attributed to high subglacial water pressure. Reconstructions and consolidation tests on basal till of the lobe indicate that water pressures at the bed surface were, depending upon location, at least $78-98 \%$ of the ice-overburden pressure. Water pressures may have been higher, because consolidation tests yield maximum values of effective normal stress, till pore water likely flowed downward during glacier loading, and drying of till may have caused consolidation in excess of that due to glacier loading. High basal water pressures are consistent with the hydrological model of Walder and Fowler (1994), which predicts flow in shallow, wide channels cut into the bed, not unlike the tunnel channels of the DML. These channels may have been fed by water in a layer like that which may feed WalderFowler channels beneath Whillans Ice Stream (Engelhardt and Kamb, 1997). High water pressures are also consistent with the undrained bed considered by Tulaczyk and others (2000) for Whillans Ice Stream and with preconsolidation stresses determined for the basal sediment there (Tulaczyk and others, 2001).

Calculations of the strength of the coupling between the ice and the bed indicate that, except for the case of an exceptionally thin water layer separating ice from the bed $(<0.1 \mathrm{~mm})$, ice motion was likely focused at the glacier sole. The dominant mechanism of motion was probably plowing, with the smallest particles in contact with ice stationary relative to adjacent till and accommodated by regelation.

Till-fabric data agree generally, but not completely, with the model prediction that motion of the DML was focused near the ice/bed interface. The weak alignment of clasts measured in this study indicates that in many locations the bed was not sheared to strains greater than $\sim 2$, unless another process disrupted the clast fabric or deformation was sufficiently localized along slip surfaces so that most clasts did not rotate during shear. However, strong fabrics have sometimes been reported by others for the basal till of the DML (e.g. Kemmis, 1991), leaving open the possibility of pervasive bed deformation in some areas. A more comprehensive study would consider other geomorphic and sedimentological factors indicative of the mode of basal motion. However, for former glacier beds that consist of massive till units, we know of no characteristic other than till fabric that allows small pervasive shear strains to be distinguished from the very large strains required of the bed-deformation model of glacier motion (Hooyer and Iverson, 2000).

The results of this study indicate that the DML was likely decoupled from its bed over much of its area, although this conclusion is not definitive due to uncertainties regarding application of the plowing model and interpretation of tillfabric data. The lack of a more definitive result is not surprising, since beneath even modern glaciers, where direct measurements are possible, the dominant mode of basal motion is difficult to determine and commonly ambiguous (e.g. Kamb, 2001). If the DML did decouple from its bed over much of its area, then transport of sediment occurred primarily in basal ice rather than in a shearing till layer beneath the ice. Based on modeling, ice-lobe reconstructions and field evidence, similar conclusions have been reached for the Puget lobe of the Cordilleran ice sheet (Brown and others, 1987) and a portion of the Fennoscandian ice sheet in northwest Germany (Piotrowski and Kraus, 1997; Piotrowski and Tulaczyk, 1999). In contrast, basal motion is assumed to have occurred by bed deformation in many models of Pleistocene ice masses (Boulton, 1996; Clark and others, 1996; Jenson and others, 1996; Licciardi and others, 1998; Dowdeswell and Siegert, 1999). Other studies have called upon bed deformation to account for large basal sediment fluxes (Alley, 1991; Jenson and others, 1995; Hooke and Elverhøi, 1996; Shipp and others, 1999). Our analyses and data indicate that beneath the DML widespread deformation of the bed was unlikely.

\section{ACKNOWLEDGEMENTS}

We thank B. Hubbard and S. Tulaczyk for insightful, critical reviews of the manuscript. N. F. Glasser did an excellent job handling the paper as Scientific Editor. We also thank T.J. Kemmis for sharing unpublished till-fabric data with us. This work was supported, in part, by U.S. National Science Foundation grant OPP-9725360.

\section{REFERENGES}

Alley, R. B. 1989. Water-pressure coupling of sliding and bed deformation: II. Velocity-depth profiles. F. Glaciol., 35(119), 119-129.

Alley, R. B. 1991. Deforming-bed origin for southern Laurentide till sheets? 7. Glaciol., 37(125), 67-76.

Alley, R. B., D. D. Blankenship, C. R. Bentley and S.T. Rooney. 1986. Deformation of till beneath Ice Stream B, West Antarctica. Nature, 322(6074), 57-59.

Alley, R. B., D. D. Blankenship, C. R. Bentley and S. T. Rooney. 1987. Till beneath Ice Stream B. 3. Till deformation: evidence and implications. 7. Geophys. Res., 92(B9), 8921-8929.

Baker, R. G. 1996. Pollen and plant macrofossils. In Bettis, E. A., D. J. Quade and T. J. Kemmis, eds. Hogs, bogs, and logs: Quaternary deposits and environmental geology of the Des Moines Lobe. Ames, IA, Iowa Department of Natural Resources, 105-109. (Guidebook Series 18.)

Benn, D. I. and D. J. A. Evans. 1996. The interpretation and classification of subglacially-deformed materials. Quat. Sci. Rev., 15(1), 23-52.

Bennett, M. R., R. I. Waller, N. F. Glasser, M. J. Hambrey and D. Huddart. 1999. Glacigenic clast fabrics: genetic fingerprint or wishful thinking? $\mathcal{F}$. Quat. Sci., 14(2), 125-135.

Bettis, E. A., D. J. Quade and T. J. Kemmis. 1996. Overview. In Bettis, E. A., D. J. Quade and T. J. Kemmis, eds. Hogs, bogs, and logs: Quaternary deposits and environmental geology of the Des Moines Lobe. Ames, IA, Iowa Department of Natural Resources, 1-79. (Guidebook Series 18.)

Blake, E.W., U. H. Fischer and G. K. C. Clarke. 1994. Direct measurement of sliding at the glacier bed. F. Glaciol., 40(136), 595-599.

Boulton, G. S. 1987. A theory of drumlin formation by subglacial sediment deformation. In Menzies, J. and J. Rose, eds. Drumlin Symposium. Rotterdam, A. A. Balkema, 25-80.

Boulton, G. S. 1996. Theory of glacial erosion, transport and deposition as a consequence of subglacial sediment deformation. F. Glaciol., 42(140), 43-62.

Boulton, G. S. and K. E. Dobbie. 1993. Consolidation of sediments by glaciers: relations between sediment geotechnics, soft-bed glacier dynamics and subglacial ground-water flow. F. Glaciol., 39(131), 26-44.

Boulton, G. S. and R. C. A. Hindmarsh. 1987. Sediment deformation beneath glaciers: rheology and geological consequences. 7. Geophys. Res., 92(B9), 9059-9082.

Brevik, E. 2000. Limits to ice thickness in Iowa during the LateWisconsinan. 7. Iowa Acad. Sci., 107 (2), 46-50.

Brown, N. E., B. Hallet and D. B. Booth. 1987. Rapid soft bed sliding of the Puget glacial lobe. 7. Geophys. Res., 92(B9), 8985-8997.

Burras, C. L. and W. H. Scholtes. 1987. Basin properties and post-glacial erosion rates of minor moraines in Iowa. Soil Sci. Soc. Am. F., 51 (6), 1541-1547.

Casagrande, A. 1936. The determination of the preconsolidation load and its practical significance. In First International Conference on Soil Mechanics and Foundation Engineering. Proceedings. Vol. 3. Cambridge, MA, 60-64.

Clark, P. U. 1991. Striated clast pavements: products of deforming subglacial sediment? Geology, 19(5), 530-533.

Clark, P. U. 1992. Surface form of the southern Laurentide ice sheet and its 
implications to ice-sheet dynamics. Geol. Soc. Am. Bull., 104(5), 595-605.

Clark, P. U. 1994. Unstable behavior of the Laurentide ice sheet over deforming sediment and its implications for climate change. Quat. Res., $41(1), 19-25$.

Clark, P. U. and J. S. Walder. 1994. Subglacial drainage, eskers, and deforming beds beneath the Laurentide and Eurasian ice sheets. Geol. Soc. Am. Bull., 106(2), 304-314.

Clark, P. U., J. M. Licciardi, D. R. MacAyeal and J.W. Jenson. 1996. Numerical reconstruction of a soft-bedded Laurentide ice sheet during the last glacial maximum. Geology, 24(8), 679-682.

Clark, P. U., R. B. Alley and D. Pollard. 1999. Northern Hemisphere icesheet influences on global climate change. Science, 286(5442), 1104-1111.

Clayton, L. and S. R. Moran. 1982. Chronology of Late Wisconsinan glaciation in middle North America. Quat. Sci. Rev., 1(1), 55-82.

Clayton, L., J.T. Teller and J.W. Attig, Jr. 1985. Surging of the southwestern part of the Laurentide ice sheet. Boreas, 14(3), 235-241.

Clayton, L., D. M. Mickelson and J.W. Attig. 1989. Evidence against pervasively deformed bed material beneath rapidly moving lobes of the southern Laurentide ice sheet. Sediment. Geol., 62(3-4), 203-208.

Colgan, P. M. 1996. The Green Bay and Des Moines lobes of the Laurentide ice sheet: evidence for stable and unstable glacier dynamics 18,000 to 12,000 BP. (Ph.D. thesis, University of Wisconsin-Madison.)

Colgan, P. M. 1999. Reconstruction of the Green Bay lobe, Wisconsin, United States, from 26,000 to 13,000 radiocarbon years B.P. In Mickelson, D. M. and J.W. Attig, eds. Glacial processes: past and present. Boulder, CO, Geological Society of America, 137-150. (Special Paper 337.)

Colgan, P. M. and D. M. Mickelson. 1997. Genesis of streamlined landforms and flow history of the Green Bay lobe, Wisconsin, U.S.A. Sediment. Geol., $111(1-4), 7-25$

Das, B. M. 1994. Principles of geotechnical engineering. Boston, MA, PWS Publishing Company.

Dowdeswell, J. A. and M. J. Siegert. 1999. Ice-sheet numerical modelling and marine geophysical measurements of glacier-derived sedimentation on the Eurasian Arctic continental margins. Geol. Soc. Am. Bull., 111(2), 1080-1097.

Engelhardt, H. and B. Kamb. 1997. Basal hydraulic system of a West Antarctic ice stream: constraints from borehole observations. f. Glaciol., 43(144), 207-230.

Engelhardt, H. and B. Kamb. 1998. Basal sliding of Ice Stream B, West Antarctica. F. Glaciol., 44(147), 223-230.

Evenson, E. B. 1971. The relationship of macro- and microfabric of till and the genesis of glacial landforms in Jefferson County, Wisconsin. In Goldthwait, R. P., ed. Till: a symposium. Columbus, $\mathrm{OH}$, Ohio State University Press, 345-364.

Fischer, U. H. and G. K. C. Clarke. 1997. Stick-slip sliding behaviour at the base of a glacier. Ann. Glaciol., 24, 390-396.

Fitzsimons, S. J. 1997. Depositional models for moraine formation in East Antarctic coastal oases. F. Glaciol., 43(144), 256-264.

Gwynne, G. S. 1942. Swell and swale pattern of the Mankato lobe of the Wisconsin drift plain in Iowa. 7. Geol., 50(2), 200-208.

Gwynne, C. S. 1951. Minor moraines in South Dakota and Minnesota. Geol. Soc. Am. Bull., 62 (3), 233-250.

Hallberg, G. R. and T. J. Kemmis. 1986. Stratigraphy and correlation of the glacial deposits of the Des Moines and James lobes and adjacent areas in North Dakota, Minnesota, and Iowa. Quat. Sci. Rev., 5, 65-68.

Hooke, R. LeB. 1970. Morphology of the ice-sheet margin near Thule, Greenland. 7. Glaciol., 9(57), 303-324.

Hooke, R. LeB. and A. Elverhøi. 1996. Sediment flux from a fjord during glacial periods, Isfjorden, Spitsbergen. Global Planet. Change, 12(1-4), 237-249.

Hooke, R. LeB., B. Hanson, N. R. Iverson, P. Jansson and U. H. Fischer. 1997. Rheology of till beneath Storglaciären, Sweden. f. Glaciol., 43(143), 172-179

Hooyer, T. S. 1999. Laboratory studies of till deformation with implications for the flow mechanism of the Des Moines Lobe. (Ph.D. thesis, Iowa State University.)

Hooyer, T. S. and N. R. Iverson. 2000. Clast-fabric development in a shearing granular material: implications for subglacial till and fault gouge. Geol. Soc. Am. Bull., 112(5), 683-692.

Humphrey, N., B. Kamb, M. Fahnestock and H. Engelhardt. 1993. Characteristics of the bed of the lower Columbia Glacier, Alaska. 7. Geophys. Res., 98(B1), 837-846.

Iverson, N. R. 1999. Coupling between a glacier and a soft bed. II. Model results. F. Glaciol., 45(149), 41-53.

Iverson, N. R., B. Hanson, R. LeB. Hooke and P. Jansson. 1995. Flow mechanism of glaciers on soft beds. Science, 267(5194), 80-81.

Iverson, N. R., R.W. Baker and T. S. Hooyer. 1997. A ring-shear device for the study of till deformation: tests on tills with contrasting clay contents. Quat. Sci. Rev., 16(9), 1057-1066.
Iverson, N. R., T. S. Hooyer and R. W. Baker. 1998. Ring-shear studies of till deformation: Coulomb-plastic behavior and distributed strain in glacier beds. 7. Glaciol., 44(148), 634-642.

Jeffery, G. B. 1922. The motion of ellipsoidal particles immersed in a viscous fluid. Proc. R. Soc. London, Ser. A, 102 (715), 161-179.

Jenson, J., P. U. Clark, D. R. MacAyeal, C. Ho and J. C. Vela. 1995. Numerical modelling of advective transport of saturated deforming sediment beneath the Lake Michigan lobe, Laurentide ice sheet. Geomorphology, 14(2), 157-166.

Jenson, J.W., D. R. MacAyeal, P. U. Clark, C. L. Ho and J. C. Vela. 1996. Numerical modeling of subglacial sediment deformation: implications for the behavior of the Lake Michigan lobe, Laurentide ice sheet. 7. Geophys. Res., 101 (B4), 8717-8728.

Kamb, B. 2001. Basal zone of the West Antarctic ice streams and its role in lubrication of their rapid motion. In Alley, R. B. and R. A. Bindschadler, eds. The West Antarctic ice sheet: behavior and environment. Washington, DC, American Geophysical Union, 157-199. (Antarctic Research Series 77.)

Kanwar, R. S., J. L. Baker, R. Horton, R. L. Handy, L. Jones and A. Luttenegger. 1990. Aquitard hydrology project, Ames research site, annual project report. Ames, IA, Iowa Department of Natural Resources. Geological Survey Bureau.

Kanwar, R. S., J. L. Baker, R. Horton, L. Jones, W. W. Sumpkins and A. Luttenegger. 1992. Aquitard hydrology project, Ames research site, annual project report. Ames, IA, Iowa Department of Natural Resources. Geological Survey Bureau.

Kemmis, T. J. 1991. Glacial landforms, sedimentology, and depositional environments of the Des Moines Lobe, northern Iowa. (Ph.D. thesis, University of Iowa.)

Kemmis, T. J., G. R. Hallberg and A. J. Luttenegger. 1981. Depositional environments of glacial sediments and landforms on the Des Moines lobe, Iowa: a field trip guide with research papers for the meeting of the North-Central Section of the Geological Society of America. Iowa City, IA, Iowa Geological Survey. (Guidebook 6.)

Kirkbride, M. P. 1995. Processes of transportation. In Menzies, J., ed. Modern glacial environments: processes, dynamics and sediments. Vol. 1. Glacial environments. Oxford, etc., Butterworth-Heinemann, 261-292.

Krüger, J. and H. H. Thomsen. 1984. Morphology, stratigraphy, and genesis of small drumlins in front of the glacier Myrdalsjökull, south Iceland. $\mathcal{F}$. Glaciol., 30 (104), 94-105.

Lambe, T.W. and R.V. Whitman. 1969. Soil mechanics. New York, etc., John Wiley and Sons.

Licciardi, J. M., P. U. Clark, J.W. Jenson and D. R. MacAyeal. 1998. Deglaciation of a soft-bedded Laurentide ice sheet. Quat. Sci. Rev., 17(4-5), 427448.

Lliboutry, L. 1979. Local friction laws for glaciers: a critical review and new openings. F. Glaciol., 23 (89), 67-95.

Luttenegger, A. J., T. J. Kemmis and G. R. Hallberg. 1983. Origin and properties of glacial till and diamictons. In Yong, R. N., ed. Geological Environment and Soil Properties, 17-21 October 1983, Houston, Texas. American Society of Civil Engineers, 310-331. (ASCE Special Publication.)

MacAyeal, D. R. 1993. Binge/purge oscillations of the Laurentide ice sheet as a cause of the North Atlantic's Heinrich events. Paleoceanography, 8(6), $775-784$.

Mark, D. M. 1973. Analysis of axial orientation data, including till fabrics. Geol. Soc. Am. Bull., 84(4), 1369-1373.

Marshall, S. J. and G. K. C. Clarke. 1997. A continuum mixture model of ice stream thermomechanics in the Laurentide ice sheet. 1. Theory. F. Geophys. Res., 102(B9), 20,599-20,614.

Mathews, W. H. 1974. Surface profiles of the Laurentide ice sheet in its marginal areas. 7. Glaciol., 13(67), 37-43.

Matsch, C. L. 1972. Quaternary geology of southwestern Minnesota. In Sims, P. K. and G. B. Morey, eds. Geology of Minnesota: a centennial volume. St Paul, MN, Minnesota Geological Survey, 548-560.

Mickelson, D. M. 1987. Central lowlands. In Graf, W. L., ed. Geomorphic Systems of North America. Boulder, CO, Geological Society of America, 111-118. (Decade of North American Geology Centennial Special Volume 2.)

Mickelson, D. M., L. J. Acomb and T. B. Edil. 1979. The origin of preconsolidated and normally consolidated tills in eastern Wisconsin, U.S.A. In Schlüchter, C., ed. Moraines and varves: origin/genesis/classification. Rotterdam, A.A. Balkema, 179-187.

Østrem, G. 1971. Rock glaciers and ice-cored moraines: a reply to D. Barsch. Geogr. Ann., 53A(3-4), 207-213.

Paterson, W. S. B. 1994. The physics of glaciers. Third edition. Oxford, etc., Elsevier. Patterson, C. J. 1996. The glacial geology of southwestern Minnesota with emphasis on the deposits and dynamics of the Des Moines Lobe. (Ph.D. thesis, University of Minnesota.)

Piotrowski, J. A. and A. M. Kraus. 1997. Response of sediment to ice-sheet loading in northwestern Germany: effective stresses and glacier-bed stability. F. Glaciol., 43(145), 495-502.

Piotrowski, J. A. and S. Tulaczyk. 1999. Subglacial conditions under the last 
ice sheets in northwest Germany: ice-bed separation and enhanced basal sliding? Quat. Sci. Rev., 18(6), 737-751.

Piotrowski, J. A., D. M. Mickelson, S. Tulaczyk, D. Krzyszkowski and F.W. Junge. 2001. Were deforming subglacial beds beneath past ice sheets really widespread? Quat. Int., 86(1), 139-150.

Porter, P. R. and T. Murray. 2001. Mechanical and hydraulic properties of till beneath Bakaninbreen, Svalbard. f. Glaciol., 47(157), 167-175.

Porter, P. R., T. Murray andJ. A. Dowdeswell. 1997. Sediment deformation and basal dynamics beneath a glacier surge front: Bakaninbreen, Svalbard. Ann. Glaciol., 24, 21-26.

Röthlisberger, H. 1972. Water pressure in intra- and subglacial channels. $\mathcal{f}$. Glaciol., 11(62), 177-203.

Sauer, E. K., A. K. Egeland and E. A. Christiansen. 1993. Preconsolidation of tills and intertill clays by glacial loading in southern Saskatchewan, Canada. Can. 7. Earth Sci., 30(3), 420-433.

Schwert, D. P. and H. J. Torpen. 1996. Insect remains: a faceted eye's perspective on the advance of the Des Moines Lobe into north-cental Iowa. In Bettis, E. A., D. J. Quade and T.J. Kemmis, eds. Hogs, bogs, and logs: Quaternary deposits and environmental geology of the Des Moines Lobe. Ames, IA, Iowa Department of Natural Resources, 99-104. (Guidebook Series 18.)

Shipp, S. S., J. B. Anderson and E.W. Domack. 1999. Late PleistoceneHolocene retreat of the West Antarctic ice-sheet system in the Ross Sea: Part 1 - geophysical results. Geol. Soc. Am. Bull., 111 (10), 1486-1516.

Skempton, A. W. 1985. Residual strength of clays in landslides, folded strata and the laboratory. Géotechnique, 35(1), 3-18.

Smalley, I. J. and D. J. Unwin. 1968. The formation and shape of drumlins and their distribution and orientation in drumlin fields. F. Glaciol., 7(51), 377-390.

Socha, B. J., P. M. Colgan and D. M. Mickelson. 1999. Ice-surface profiles and bed conditions of the Green Bay Lobe from 13,000 to $11,000{ }^{14} \mathrm{C}$ years B.P. In Mickelson, D. M. and J.W. Attig, eds. Glacial processes: past and present. Boulder, CO, Geological Society of America, 151-158. (Special Paper 337.)

Solheim, A., G. F. Forsberg and A. Pittenger. 1991. Stepwise consolidation of glacigenic sediments related to the glacial history of Prydz Bay, East Antarctica. In Barron, J. and B. Larsen, eds. Kerguelen Plateau-Prydz Bay. Vol. 119. College Station, Texas, Texas A and M University, 169-182. (Ocean Drilling Program, Scientific Results.)

Stanford, S. D. and D. M. Mickelson. 1985. Till fabric and deformational structures in drumlins near Waukesha, Wisconsin, U.S.A. F. Glaciol., 31 (109), 220-228.

Stewart, R. A., D. Bryant and M. J. Sweat. 1988. Nature and origin of corrugated ground moraine of the Des Moines Lobe, Story County, Iowa. Geomorphology, $\mathbf{1}(2), 111-130$.

Stuiver, M. and 9 others. 1998. INTERCAL98 radiocarbon age calibration, 24,000-0 cal BP. Radiocarbon, 40 (3), 1041-1083.

Tika, T. E., P. R. Vaughan and L. J. Lemos. 1996. Fast shearing of pre-existing shear zones in soil. Géotechnique, 46(2), 197-233.

Truffer, M., W. D. Harrison and K. A. Echelmeyer. 2000. Glacier motion dominated by processes deep in underlying till. f. Glaciol., 46(153), 213-221.

Tulaczyk, S. 1999. Ice sliding over weak, fine-grained tills: dependence of icetill interactions on till granulometry. In Mickelson, D. M. and J.W. Attig, eds. Glacial processes: past and present. Boulder, CO, Geological Society of America, 159-177. (Special Paper 337.)

Tulaczyk, S. M., B. Kamb and H. F. Engelhardt. 2000. Basal mechanics of Ice Stream B, West Antarctica. II. Undrained-plastic-bed model. 7. Geophys. Res., $105(\mathrm{Bl})$, 483-494.

Tulaczyk, S., B. Kamb and H. F. Engelhardt. 2001. Estimates of effective stress beneath a modern West Antarctic ice stream from till preconsolidation and void ratio. Boreas, $\mathbf{3 0}(2), 101-114$

Walder, J. S. and A. Fowler. 1994. Channelized subglacial drainage over a deformable bed. f. Glaciol., 40(134), 3-15.

Wright, H. E., Jr, C. L. Matsch and E. J. Cushing. 1973. Superior and Des Moines lobes. Geol. Soc. Am. Mem., 136, 153-185.

\section{APPENDIX}

\section{PRECONSOLIDATION TESTING}

\section{Sampling and testing procedure}

Intact samples of the DML basal till were collected by exposing a $0.04 \mathrm{~m}^{2}$ platform in unweathered basal till at the base of an outcrop. A standard thin-walled brass cylinder,

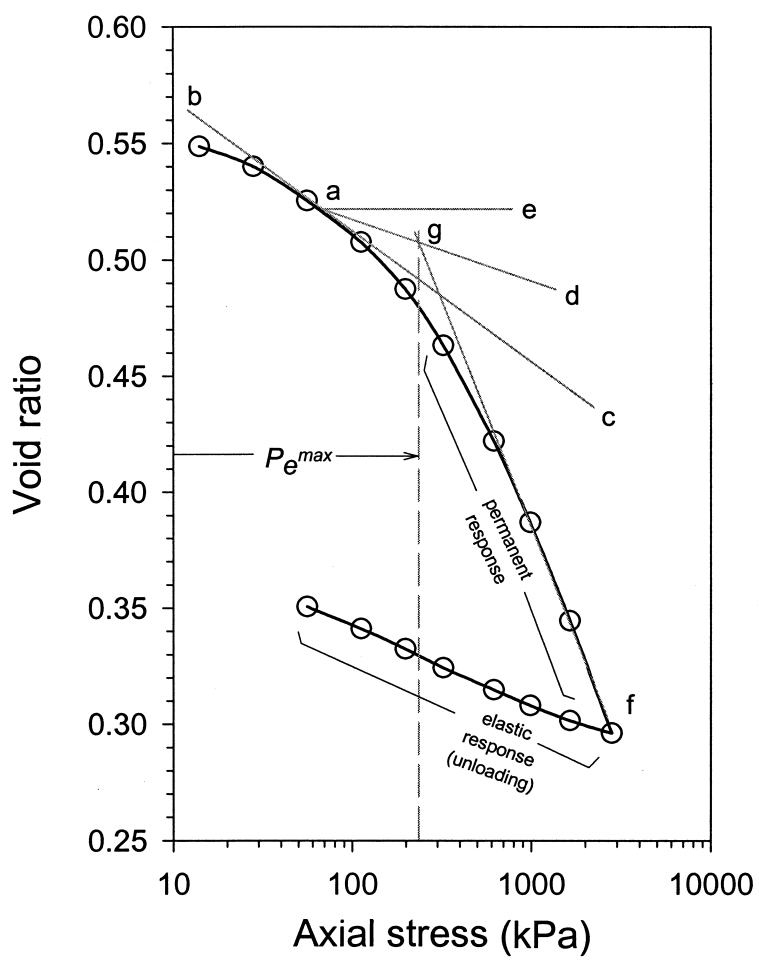

Fig. 10. Typical consolidation curve for the DML basal till. Labeled line segments refer to the graphical method of Casagrande (1936) for determining preconsolidation stress, as explained in the Appendix.

$16 \mathrm{~mm}$ high by $75 \mathrm{~mm}$ in diameter, was pushed downward into the till until it was flush with the platform. The till around and below the cylinder was then removed, leaving an intact specimen. A wire saw was used to trim the top and bottom of the specimen. Specimens were transported to the laboratory, inserted in a fixed-ring consolidometer, saturated with water, and loaded incrementally following a standard procedure (Das, 1994, p. 250). Axial stress increments were applied no less than every 24 hours, thereby allowing sufficient time for excess pore-water pressure to dissipate.

\section{Data reduction}

The preconsolidation stress, $P_{\mathrm{e}}^{\mathrm{max}}$, was determined for each specimen by plotting void ratio as a function of the log of the axial stress (Fig. 10). An abrupt change in the slope of this plot indicates the transition from dominantly elastic to permanent deformation and hence the value of $P_{\mathrm{e}}^{\max }$. Unfortunately, this change in slope is almost never abrupt but occurs gradually over a range of axial stress (Lambe and Whitman, 1969, p. 297).

To determine $P_{\mathrm{e}}^{\max }$ from such plots, the empirical method of Casagrande (1936) was used. A point was first established visually at the minimum radius of curvature (see "a" in Fig. 10). Two lines were drawn through this point: one tangent to the curve (bc) and the other horizontal (ae). The acute angle formed by these two lines was then bisected (ad). A straight line (fg) was extended from the lower portion of the consolidation curve until it intersected this bisector $(\mathrm{ad})$. The abscissa at this point of intersection is $P_{\mathrm{e}}^{\max }$. Casagrande found that this method reproduced preconsolidation stresses on soil specimens with known loading histories. 